\title{
Имплементация Римского Статута Международного уголовного суда: новый немецкий кодекс преступлений против международного права
}

\section{Сафаров Н.А.*}

Принятие нового немецкого Кодекса преступлений против международного права (Völkerstrafgesetzbuch)' (далее по тексту - КППМП либо Кодекс) явилось одним из важнейших этапов имплементации Римского статута Международного уголовного суда (далее-МУС или Суд), хотя это и выходит за рамки собственно имплементационного процесса. Дело в том, что указанный акт основывался не только на Римском статуте, но и на других известных договорных источниках, в частности таких, как Женевские конвенции 1949 г. и Дополнительные протоколы к ним, Конвенция о защите культурных ценностей в случае вооруженного конфликта 1954 г., и представляет собой консолидированный юридический документ, криминализировавший серьезные нарушения международного гуманитарного права. Тем самым новый Кодекс учел положения ст. 10 Римского статута, которая предусматривает, что часть 2 Статута в сфере определения преступлений не должна истолковываться как каким бы то ни было образом ограничивающая ныне действующие или складывающиеся нормы международного права или наносяшая им ушерб для целей, отличных от целей Статута.

Как известно, Федеративная Республика Германии была активно вовлечена в процесс учреждения Международного уголовного суда и оказалась 25-м государством, которое ратифицировало его Статут (11 декабря 2000 г. $)^{2}$. Еще во время подписания Римского статута 9 де-

\footnotetext{
'Сафаров Низами Абдуллаевич - к.ю.н., заведующий отделом административного и военного законодательства Аппарата Национального Собрания (Парламента) Азербайджанской Республики.

'Английская версия акта называется Code of Crimes Against International Law (CCAIL), и обычно этот вариант используется в англоязычных публикациях.

2О государствах - участниках Римского статута МУС см.: [WWW-сайт]: URL:http:// untreaty.un.org/ENGLISH/bible/englishinternetbible/part//chapterXVIII/treaty10.asp (2004. 6 января).
} 
кабря 1998 г. правительство Германии заявило о намерении адаптировать немецкое уголовное законодательство к его нормам и положениям международного гуманитарного права. В этих целях в октябре 1999 г. была создана рабочая группа, в которую вошли представители министерств юстиции, иностранных дел, обороны и 6 экспертов, обладающих признанным авторитетом в области международного уголовного права. В мае 2000 г. указанная группа завершила свою работу и передала подготовленный проект Министерству юстиции ФРГ. Именно данный проект составил основу нового Кодекса и был впоследствии принят лишь с незначительными изменениями ${ }^{3}$.

В целом же, стратегия федерального правительства Германии по имплементации Статута МУС основывалась на трехэтапной процедуре внесения изменений во внутреннее законодательство.

Первым важнейшим шагом явилось обеспечение согласованности между Основным Законом Германии и Статутом. Данный этап завершился 11 декабря 2000 г. передачей на хранение ратификационной грамоты. Однако до ратификации был принят законопроект о внесении изменений в Конституцию страны, в результате которого был урегулирован один из наиболее сложных вопросов обеспечения согласованности Статута МУС с нормами национального законодательства в связи с возможной передачей собственных граждан под юрисдикцию международных уголовных трибуналов.

Как известно, среди различных видов сотрудничества, предусмотренных разделом 9 Римского статута, одним из важнейших является передача обвиняемых, которая осуществляется безотносительно к правовому статусу лица, и в частности, к его гражданству ${ }^{4}$. В этой связи указанная процедура создала серьезную конституционную проблему для стран, принявших решение о ратификацин Статута МУС, поскольку в подавляющем большинстве случаев государства отказывают в экстрадиции собственных граждан ${ }^{5}$. Механическое распространение об-

${ }^{3}$ Кодекс вступил в силу с 30 июня 2002 г.

${ }^{4} \mathrm{CM}$. подробнее: Bassiouni C. Introduction to International Criminal Law. Transnational Publishers. 2003; Knoops A. An Introduction to the Law of International Criminal Tribunals: A Comparative Study. Transnational Publishers. 2003.

${ }^{5}$ См. об этом подробнее: Kress $C$. Prost $K$. 'Article 89 - Surrender of persons to the Court', in Commentary on the Rome Statute of the International Criminal Court: Observers' Notes, Article by Article / Otto Triffierer (ed.). I Aufl. Baden-Baden. Nomos. 1999. P. 10711079; Swart B. 'Arrest and Surrender', in The Rome Statute of the International Criminal Court: A Commentary/Ed. by Cassese A., Gaeta P., Jones R.W.D. Jones. Oxford: Oxford 
щих экстрадиционных запретов на передачу обвиняемых МУС по существу могло бы означать полное блокирование деятельности последнего и препятствовало бы осуществлению юрисдикции нового международного судебного учреждения. В этой связи для урегулирования вопросов совместимости Статута с системой национального законодательства Германией был избран путь конституционных реформ.

Законом от 29 ноября 2000 г. об изменении ст. 16 Конституции ФРГ (вступил в силу 2 декабря 2000 г.), в отступление от принципа невыдачи собственных граждан, была предусмотрена возможность экстрадиции немцев в государства - члены Европейского Союза или передачи международному суду при условии соблюдения принципов верховенства права. При этом изменения, внесенные в немецкое законодательство, сопровождались как содержательным, так и терминологическим размежеванием двух процедур. В частности, термин «экстрадиция» ("Auslieferung") был заменен термином «передача» (“Ueberstellung") в контексте сотрудничества с международными трибуналами ${ }^{6}$.

Другим этапом явилось принятие Закона об имплементации, включающего в себя все те изменения, которые Германия должна была внести в законодательство в соответствии с Римским статутом. На третъем этапе был разработан и принят Кодекс преступлений против международного права ${ }^{7}$.

University Press. 2002. Vol. II. P. 1639-1704; Knoops A. Surrender to the International Criminal Courts: Contemporary Practise and Procedures. Transnational Publishers. 2002. Р. 195-197; Тузмухамедов Б.Р. Римский статут Международного уголовного суда: возможные вопросы конституционности // Московский журнал международного права. 2002. № 2. С. 165-173; Сафаров Н.A. Передача лиц Международному уголовному суду и институт зкстрадиции: трудный компромисс// Mocковский журнал международного права. 2003. № 2. С. 165-173.

${ }^{6}$ Wilęitzki P. The German Law on Co-operation with ICC // International Criminal Law Review. 2002. Vol. 2. ą 2. P. 195-212.

${ }^{7} \mathrm{C}_{\mathrm{M}}$. подробнее: Jarasch $F$., Kress $C$. "The Rome Statute and the German Legal Order", in Kress C., Lattanzi $F$. The Rome Statute of the International Criminal Court and Domestic Legal Orders. Vol. 1. General Aspects and Constitutional Issues. Ripa Fagnano Alto / Baden-Baden. 2000. P. 91-112. Кресс К. Ратификация и имплементация Статута Международного уголовного суда в Германии // Международный уголовный суд: ратификация и имплементация на национальном уровне. Материалы международной конференции. М. 2001. C. 108-115; Werle G. Das Völkerstrafgesetzbuch // Juristenzeitung. 2002. Vol. 57. a 15/16. S. 725-734; Zimmermann A. Auf dem Weg zu einem deuttschen Völkerstrafgesetzbuch: Entstehung, völkerrechtlicher Rahmen und wesentliche Inhalte // Zeitttschrift für Rechtpolitik. 2002. Vol. 35. ą 3. S. 97-102. 
Криминализация немецким законодателем преступлений, подпадающих под юрисдикцию МУС, имела самое существенное значение, поскольку, с одной стороны, позволила имплементировать договорные обязательства Германии, а также реализовать нормы международного обычного права в сфере пресечения международных преступлений, в борьбе с которыми проявляет заинтересованность все международное сообщество, а с другой стороны, создала необходимые правовые предпосылки для самостоятельного преследования геноцида, военных преступлений и т.д., сведя к минимуму ситуации, когда дело может быть согласно принципу дополнительности (complementarity) принято к производству $\mathrm{MУC}^{8}$.

Как известно, дополнительность является основным концептуальным принципом деятельности Суда. Его значение подчеркивается уже в Преамбуле Римского статута, где отмечается, что Международный уголовный суд, учрежденный на основании настоящего Статута, дополняет национальные органы уголовной юстиции ${ }^{9}$. Это означает, что основная нагрузка в борьбе с международными преступлениями ложится на государства, являющиеся участниками договора о создании Суда. МУС может осуществить свою юрисдикцию лишь в тех случаях, когда государство не в состоянии (unable) либо не желает (unwilling) преследовать обвиняемых ${ }^{10}$. Однако для того, чтобы государства -

${ }^{8}$ См. об этом подробнее: Kleffner $K$. The Impact of Complementarity on National Implementation of Substantive International Criminal Law / Journal of International Criminal Justice. 2003. Vol. 1. № 1. P. 86-113.

${ }^{9} \mathrm{Cm}$.: Cassese A. The Statute of the International Criminal Court: Some Preliminary Reflections //European Journal of International Law. 1999. Vol. 10. № 1.P. 158-159. См. также: Broomhall $B$. International Justice and the International Criminal Law: Between Sovereignty and the Rule of Law. Oxford: Oxford University Press. 2003. P. 86-93.

${ }^{10} \mathrm{O}$ дополнительности см.: Bartram B. Primacy or Complementarity: Reconciling the Jurisdiction of National Courts and International Tribunals//The Yale Joumal of Intemational Law. 1998. Vol. 23. № 2. P. 383-436; Cassese A. International Criminal Law. Oxford: Oxford University Press. 2002. P. 348-352; См. об этом также: Williams S. 'Article 17 - Issues of Admissibility', in Commentary on the Rome Statute of the International Criminal Court: Obsrevers' Notes, Article by Article. P. 15; The International Criminal Court: the Making of the Rome Statute-Issues, Negotiations, Results / by Roy S. Lee (ed.). Kluwer Law International. The Hague; Boston. 1999. P. 41-78; Reflections on the International Criminal Court: Essays in Honour of Adrian Bos / ed. by Herman A.M. von Hebel, J.G. Lammers, J. Schukking. The Hague. 1999. P. 57-77; Arsanjani M. The Rome Statute of the International Criminal Court// American Journal of International Law. 1999. Vol. 93. № 1. Р. 27-28; Фисенко И.В. Борьбас международными преступлениями в международном уголовном праве. Минск. 2000. C. 136-137; Holmes J. 'Complementarity: National Courts versus the ICC', in The Rome Statute of the International Criminal Court: A Commentary. P. 667-668. 
участники МУС имели возможность возбудить уголовное преследование в отношении лиц, совершивших преступления, охваченные ст. 5 Римского статута, они должны предусмотреть в национальном законодательстве составы соответствующих деяний.

В Комментариях к Проекту кодекса указывалось, что основная цель принятия данного акта - трансформация норм Римского статута МУС, хотя в более широком плане речь идет о гармонизации германского уголовного права и обеспечении преимущественно национального уголовного преследования лиц, виновных в совершении геноцида, преступлений против человечности, военных преступлений.

Структурно новый Кодекс охватил два раздела - Общие положения ("Algemeine Regelungen"), предусматриваюшие соответствующие предпосылки уголовной ответственности виновньх лиц, и Особенную часть ("Straftaten gegen das Völkerrecht"), охватывающую составы криминализуемых деяний.

Обращает на себя внимание, что Общая часть КППМП не содержит целого ряда положений, которые традиционны для данной части (субъективная сторона преступления, возраст уголовной ответственности, вменяемость и т.п.), поскольку абсолютное большинство норм Общей части УК Германии (“Allgemeiner Teil") применимо в отношении преступлений, предусмотренных новым Кодексом. В этой связи разработчиками проекта нового Кодекса было принято обоснованное решение о том, чтобы вместо введения в новый акт предусмотренных Римским статутом норм об общих принципах уголовного права ${ }^{11}$ (nullum crimen sine lege, nulla poena sine lege, отсутствие обратной силы ratione personae)-cт. 22-24, соучастии и покушении на преступление - cr. 25, возрасте уголовной ответственности - ст. 26, субъективной стороне преступления - ст. 30, основаниях освобождения от уголовной ответственности - ст. 31 применять соответствующие нормы Общей части УК Германии.

Согласно $\$ 2$ к деяниям, предусмотренным Кодексом, применяется общее уголовное право. Что же касается включенных в Кодекс отдель-

"См. об этом: Schabas W. General Principles of Criminal Law in the International Criminal Court Statute (Part III) // European Journal of Crime, Criminal Law and Criminal Justice. 1998. Vol. 6 aq 4. P. 84-112; Ambos K. General Principles of Criminal Law in the Rome Statute//Criminal Law Forum. 1999. Vol. 10. ą 1. P. 1-32; Saland P. 'International Criminal Law Principles', in The International Criminal Court: the Making of the Rome Statute, Issues, Negotiations, Results. P. 189-216; Кибальник А.Г. Современное международное уголовное право. СПб. 2003. С. 91-109. 
ных норм общего характера, они относятся исключительно к тем деяниям, которые криминализированы в данном акте (исполнение приказа или распоряжения, ответственность военных командиров либо других начальников, неприменение сроков давности) ${ }^{12}$.

Как указывалось в Комментариях к проекту Кодекса, его Общая часть содержит специальные положения лишь постольку, поскольку это необходимо для трансформации Римского статута МУС.

В первую очередь хотелось бы обратить внимание на терминологическое определение преступлений, которые предусматривает новый Кодекс.

Как известно, применительно к обозначению преступлений, подпадающих под юрисдикцию Суда, Римский статут использовал различную терминологию, в частности: серьезные преступления - "grave crimes", международные преступления - “international crimes" (Преамбула), наиболее серьезные преступления, вызывающие озабоченность всего международного сообшества - "most serious crimes of concern to the international community as a whole" (Преамбула и ст. 5 (1)). Однако при этом было абсолютно ясно, что речь идет о преследовании деяний, предусмотренных ст. 5 (геноцид, военные преступления, преступления против человечности, агрессия). Надо учесть, что данная статья не отражала какой-либо формальной иерархии этих деяний, основанной на том или ином критерии (например, тяжести преступления). Все указанные преступления в равной мере представляют собой серьезнейшую опасность для международного сообщества, их совершение должно влечь уголовную ответственность, а виновные не могут оставаться безнаказанными. Новый немецкий Кодекс в отличие от Статута МУС использует для обозначения вышеназванных преступлений такие термины, как «уголовные преступления против международного права» - "Straftaten gegen das Völkerrecht" (нем.), “criminal offences against international law" (англ.), «серьезные уголовные преступления» - "Verbrechen" (нем.), "serious criminal offences" (англ.), и этой терминологией охвачены составы деяний, на которые распространяется универсальная юрисдикция.

Уже в 11 Кодекса - «Сфера применения» (“Anwendugsbereich”) предусматривается универсальная юрисдикция ${ }^{13}$ в отношении соответствующей категории деяний (геноцид, преступления против человеч-

${ }^{12}$ См. подробнее: Wirth S. Germany's New International Crimes Code: Bringing a Case to Court // Journal of International Criminal Justice. Vol. I. ą I. 2002. P. 153.

${ }^{13} \mathrm{CM.} \mathrm{об} \mathrm{этом} \mathrm{подробнее:} \mathrm{Reydams} \mathrm{L.} \mathrm{Universal} \mathrm{Jurisdiction} \mathrm{-} \mathrm{Intermational} \mathrm{and} \mathrm{National}$ Legal Perspectives. Oxford: Oxford University Press. 2003. 
ности, военные преступления). Согласно данному параграфу, нормы Кодекса применяются в отношении всех предусматриваемых им преступлений против международного права, указанных в нем серьезных преступлений и в том случае, когда деяние совершено за границей и не имеет отношения к территории Германии.

В отличие от других видов юрисдикции, предполагающих некоторую опосредованность (через территорию, на которой было совершено преступление, через гражданство обвиняемого либо потерпевшего и т.д.), универсальная юрисдикция основывается на всеобщности осуждения самого преступления ${ }^{14}$. Как указывается в Комментариях к Проекту Кодекса, ввиду особой направленности преследование этих деяний, совершенных за границей, в том числе иностранными гражданами, не является недопустимым вмешательством в суверенитет других государств.

Применение подобного типа юрисдикционной компетенции не только допустимо с точки зрения международного права, но и является ключевым требованием любой национальной правовой имплементации в сфере преследования международных преступлений ${ }^{15}$. Подобная имплементация вытекает прежде всего из участия в таких фундаментальных международно-правовых актах, как Женевские конвенции 1949 г. и Дополнительные протоколы к ним ${ }^{16}$. В частности, согласно ст. 3, общей для всех четырех Конвенций, «Каждая Высокая Договаривающаяся Сторона обязуется разыскивать лиц, обвиняемых в том, что они совершили или приказали совершить то или иное из упомянутых серьезных нарушений и, каково бы ни было их гражданство, предавать их своему суду $\rangle^{17}$. Именно Женевскими конвенциями были вве-

${ }^{14}$ Randall K. Universal Jurisdiction Under International Law// Texas Law Review. 1988. Vol. 66. № 4. P. 785-778; Van Den Vyer J. Universal Jurisdiction in International Criminal Law//South African Yearbook of International Law. 1999. Vol. 24. P. 107-132; Bassiouni $C$. Universal Jurisdiction for International Crimes: Historical Perspectives and Contemporary Practice// Virginia Journal of International Law. 2001. Vol. 42. № 1. P. 81-162; Butler H. The Doctrine of Universal Jurisdiction: A Review of the Literature // Criminal Law Forum. 2000. Vol. 11. № 3. P. 353-373; Shaw M. International Law. Cambridge: Cambridge University Press. 2003. P. 592-597.

${ }^{15} \mathrm{C}$ м. об этом: Wirth S. International Criminal Law in Germany Case Law and Legislation // Presentation to the Conference Combating International Crimes Domestically (3rd Annual War Crimes Conference, Ottawa, 22-23 April 2002).

${ }^{16} \mathrm{CM}$. подробнее: Commentary on the Additional Protocols of 8 June 1977 of the Geneva Conventions of 12 August 1949 (Eds. Sandoz, Swinarski C., Zimmermann B). Martinus Nijhoff Publishers. Geneva. 1987. 
дены договорные основания универсальной юрисдикция в отношении нарушений международного гуманитарного права, которые квалифицировались в качестве серьезных.

С другой стороны, для того, чтобы система национальной уголовной юстиции имела возможность преследовать виновных в совершении геноцида, преступлений против человечности, военных преступлений, подавляющее большинство стран предусмотрело в уголовных кодексах универсальную юрисдикцию в отношении указанной категории преступлений, которые посягают на интересы международного сообщества в целом. Кроме того, отдельными странами помимо уголовных кодексов были приняты специальные законы, распространившие универсальную юрисдикцию на некоторые международные преступления.

Примером подобной имплементации являлся, в частности, бельгийский Закон от 16 июня 1993 г. О пресечении серьезных нарушений международного гуманитарного права ("Loi relative \&agrave; la r\&eacute;pression des violations graves du droit international humanitaire") ${ }^{18}$. Напомню, что согласно ст. 7 указанного Закона, судебные инстанции Бельгии были вправе рассматривать дела о совершения нарушений, подпадающих под действие настоящего закона, независимо от места их совершения ${ }^{19}$.

Германское уголовное законодательство ранее предусматривало возможность привлечения к ответственности лиц, совершивших за пределами территории страны такие преступления, как геноцид, нападение на воздушное или водное судно, торговля людьми, незаконный сбыт наркотических веществ, подделка денег или ценных бумаг, полу-

${ }^{17}$ См. об этом, например: Van Elst $R$. Implementing Universal Jurisdiction Over Grave Breaches of the Geneva Conventions// Leiden Journal of International Law. 2000. Vol. 13. №4. P. 815-854; Brems E. Universal Criminal Jurisdiction for Grave Breaches of International Humanitarian Law//Singapore Journal of International and Comparative Law. 2002. Vol. 6. № 2. P. 909-952.

${ }^{18} \mathrm{C}$.: Vandermeersch D. La Repression en Droit Belge des Crimes de Droit International/ / Repression Nationale de Violations du Droit Internationale Humanitaire. Reunion d'Experts. Jeneva, 1997. P. 145-184; Belgium: Act Concerning the Punishment of Grave Breaches of International Humanitarian Law// International Legal Materials. 1999. Vol. XXXVIII. № 4. P. 918-925.

${ }^{19}$ Reydams L. 'Prosecuting Crimes Under International Law on the Basis of Universal Jurisdiction: The Experience of Belgium', in International and National Prosecution of Crimes Under International Law. Current Developments / Fischer H., Kress C., Luder S. (eds). Berlin Verlag. Arno Spitz Gmbx. 2001. P. 799-801. 
чение субсидий путем мошенничества, а также виновных в преступлениях, подлежащих преследованию на основании обязательного для ФРГ межгосударственного соглашения ( 7 УК Германии). Как видно из текстуального содержания ст. 7, лишь одно из преступлений, подпадающих под юрисдикцию МУС, фигурировало в данной статье. Новый Кодекс о преступлениях против международного права в четкой и ясной форме предусмотрел возможность преследования геноцида, военных преступлений, преступлений против человечности, включив их в сферу применения Закона безотносительно к такому фактору, как связь с территорией страны (т.е. Германии). Необходимо также обратить внимание на то обстоятельство, что германское уголовное законодательство не только предусмотрело возможность распространения универсальной юрисдикции на некоторые международные преступления как гипотетическую возможность преследования лиц, виновных в совершении подобных деяний ${ }^{20}$. В практике национальных судебных органов был ряд дел, связанных с применением универсальной юрисдикции в отношении преступлений, имевших место на территории бывшей Югославии.

В частности, судом Дюссельдорфа (земля Северный Рейн - Вестфалия) рассматривалось дело в отношении Йоргича (Jorgic), который обвинялся в совершении убийств, применении насилия, депортации населения на территории Боснии и Герцеговины в 1992 г. (всего 11 отдепьных эпизодов геноцида).

Обвинение основывалось на том, что Йоргич, являясь руководителем полувоенной группы осуществлял акты «этнических чисток», а в июне 1992 г. лично участвовал в казни 22 человек в городе Грабска (Grabska). В сентябре 1992 г. в центральной тюрьме Добожа (Doboj) забил до смерти заключенного. Подсудимый за акты геноцида был осужден к пожизненному заключению21 . Верховный суд ФРГ отклонил апелляцию осужденного, поскольку при рассмотрении дела в первой инстанции юрисдикция германского суда была усстановлена абсолютно правомерно, в полном соответствии с нормами уголовного законодательства ${ }^{22}$. Кроме дела Йоргича суды ФРГ рассматривали также

${ }^{20}$ См. об этом подробнее: Macedo S. Universal Jurisdiction: National Courts and the Prosecution of Serious Crimes Under International Law. University of Pennsylvania Press. 2003.

${ }^{21}$ OLG Dusseldorf, 26 September 1997.

${ }^{22}$ См. осудебной практикеФРГ по геноциду и военным преступдениям: Ambos $K$., Wirth $S$. 'Genocide and War Crimes in the Former Yugoslavia Before German Criminal Courts', in International and National Prosecution of Crimes Under International Law. P. 769-798. 
несколько других уголовных дел по обвинению в геноциде (дела Kuslic $^{23}$, Sokolovic ${ }^{24}$ и др.).

Стремление национальных судов пресекать международные преступления, в частности преступление геноцида, независимо от таких критериев, как место совершения и гражданство преступника, получает все большее распространение в судебной практике целого ряда государств. Например, в Бельгии дело по обвинению одного руандийца в совершении на территории Руанды преступлений, квалифицируемых в соответствии с бельгийским Законом от 16 июня 1993 г. как серьезные нарушения международного гуманитарного права, позволило различным судебным органам подтвердить, что суды Бельгии правомочны рассматривать деяния, расцениваемые данным законом преступными, даже если они совершены во время внутреннего конфликта за пределами территории страны и не затрагивают бельгийских граждан $^{25}$.

Судебными органами Швейцарии был осужден гражданин Руанды $\Phi$. Ньонтезе (Fulgence Niyonteze), обвиненный в совершении тяжких преступлений, совершенных в период противостояния правительственных войск (FAR) и подразделений Патриотического фронта Руанды (RPF). После получения сообщения о совершенных им деяниях Ньонтезе был задержан и привлечен к уголовной ответственности на территории Швейцарии, законодательство которой предусматривает возможность распространения универсальной уголовной юрисдикции на преступления против человечности, военные преступления и т.д. ${ }^{26} \mathrm{~B}$ результате рассмотрения уголовного дела швейцарскими судебными органами Ньонтезе был приговорен к 14 годам лишения свободы. Кстати, это дело явилось первым случаем применения на основании Женевских конвенций 1949 г. и Дополнительного протокола II к ним 1977 г. универсальной уголовной юрисдикции национальным судом в отношении лица, совершившего военные преступления в период внутреннего вооруженного конфликта. Первоначально Ньонтезе было предъявлено обвинение в геноциде, однако, учитывая, что Швейцария не яв-

${ }^{23}$ OLG Dusseldorf, 29 November 1999.

${ }^{24}$ BayObLG, 15 December 1999.

${ }^{25}$ См. об этом: Graditzky $T$. Individual Criminal Responsibility for Violations of International Humanitarian Law Committed in Non-International Armed Conflicts// International Review of the Red Cross. 1998. №. 322. P. 29-56.

${ }^{26}$ CM.: National Measures to Repress Violations of International Humanitarian Law (Civil Law Systems). Report on the Meeting of Experts. Geneva. 23-25 September 1997. P. 197-215. 
лялась участником Конвенции геноцида ${ }^{27}$ и национальное законодательство не предусматривало данного состава, суд изменил квалификацию ${ }^{28}$. Указанные примеры, а также дела из судебной практики Испании ${ }^{29}$, Италии ${ }^{30}$ и других стран свидетельствуют о попытках более широкого применения универсальной уголовной юрисдикции за серьезные нарушения международного гуманитарного права.

Отражая современные тенденции международного уголовного права и национального законодательства, новый немецкий Кодекс согласно международному договорному и обычному праву распространил на особо тяжкие преступления, посягающие на интересы международного сообщества в целом, универсальную уголовную юрисдикцию. На первый взгляд, исходя из текстуального анализа § 1 КППМП, может показаться, что речь идет об абсолютной универсальной юрисдикции, поскольку никакой оговорки о присутствии обвиняемого на территории Германии не сделано ${ }^{31}$. С другой стороны, обращает на себя внимание и тот факт, что указанная статья Кодекса не содержит каких-либо положений, ограничивающих применение универсальной юрисдикции сучетом других международных обязательств Германии, принятых в рамках многосторонних международных договоров, в ча-

${ }^{27}$ Швейцария ратифицировала Конвенцию в декабре 1999 г.

${ }^{28}$ Подробнее об этом деле см.: Reydams $L$. Nyonteze vs. Public Prosecutor // American Journal of International Law. 2002. Vol. 96. № 1. P. 236.

${ }^{39}$ Gottier $M$. 'What Relations Between the Exercise of Universal and Territorial Jurisdiction? The Decision of 13 December 2000 of the Spanish National Court Shelving the Proceedings Against Guatemalan Nationals Accused of Genocide', in International and National Prosecution of Crimes Under International Law. Current Developments. P. 843-858.

${ }^{30}$ Gaeta P. 'War Crimes Trials Before Italian Criminal Courts: New Trends', in International and National Prosecution of Crimes Under International Law. Current Developments. P. 752-769.

${ }^{31}$ В международном уголовном праве выделяют два вида универсальной юрисдикции: 1) универсальная юрисдикция in absentia, или абсолютная универсальная юрисдикция; 2) условная, или ограниченная, универсальная юрисдикция, которая предполагает присутствие обвиняемого на территории осуществляющего преследование государства. При этом международное договорное право содержит примеры применения обоих видов универсальной юрисдикции. В частности, ст. 3 , общая для Женевских конвенций, является примером абсолютной универсальной юрисдикции. В то же время такие международно-правовые акты, как Конвенция о борьбес незаконным захватом воздушных судов от 16 декабря 1970 г. (ст. 4), Международная конвенция о борьбе сфинансированием терроризма (ст. 10) и др. предусматривают возможность использования ограниченной универсальной юрисдикции, указывая на факт присутствия обвиняемого на территории правоприменяющего государства - участника конвенций. См. подробнее: Cassese A. International Criminal Law. P. 284-191. 
стности связанных с иммунитетами дипломатических представителей либо представителей международных организаций или специальных миссий. Между тем указанная проблема приобрела в последнее время самое серьезное значение в связи с тем, что некоторые государства не только предусмотрели абстрактную возможность применения универсальной юрисдикции, но и предприняли попытки ее практического осуществления в отношении преступлений, не имеющих отношения к национальной территории и совершенных, как это предполагалось со стороны правоприменяющего государства, высокими должностными лицами иностранньгх государств. В частности, попыгка применения рассматриваемого вида уголовной юрисдикции в отношении действующего министра иностранных дел Конто явилось предметом острейшего диспута между Бельгией и Демократической Республикой Конго (ДРК) по делу, которое рассматривалось Международньм судом(Congo vs. Belgium).

Суть вопроса заключалась в проблеме преследования конголезского министра г-на Ндомбаси (Mr. Yerodia Abdoulae Ndombasi), в отношении которого бельгийским судьей Д. Вандермеершем был выдан ордер на арест и экстрадицию, основанный на нарушении вышеуказанного Закона Бельгии от 1993 г. «О пресечении серьезных нарушений международного гуманитарного права».

В ответ ДРК возбудила дело в Международном суде, заявив inter alia, что бельгийский ордер на арест и ст. 5 (3) вышеуказанного Закона, на котором он основывается, противоречат международному праву, поскольку предполагают отступление от дипломатического иммунитета министра иностранных дел суверенного государства. Кроме того, представители ДРК утверждали, что сама конщепщия универсальной юрисдикции предполагает присутствие обвиняемого на территории государства, осуществляющего преследование, а ее [юрисдикции] применение противоречит международному праву. Мы не будем вдаваться во все юридические перипетии данного дела, поскольку это выходит за рамки настоящей работы ${ }^{32}$. Заметим только, что Междуна-

\footnotetext{
${ }^{32}$ Об этом деле см. подробнее: International Court of Justice: Case Concerning the Arrest Warrant of 11 April 2000 (Democratic Republic of Congo v. Belgium) // International Law Forum. Vol. 3. № 1. 2001.P. 7-8; Jennings R. Jurisdiction and Immunity in the ICJ Decision in the Yerodia Case //International Law Forum. Vol. 4. № 3. 2002. P. 99-103; Boister N. The ICJ in the Belgian Arrest Warrant Case: Arresting the Development of International Criminal Law // Joumal of Conflict and Security Law. 2002. Vol. 7. № 2. P. 293-314: Yang X. Immunity for International Crimes: A Reaffirmation of Traditional Doctrine// The Cambridge Law Journal. 2002. Vol. 61. P. 239-294; Wiskremasinghe C. Arrest Warrant of 11 April 2000
} 
родный суд тринадцатью голосами против трех определил, что выдача ордера на арест г-на Ндомбаси от 11 апреля 2000 г. и его международное обращение представляет собой нарушение правового обязательства Королевства Бельгии перед ДРК, поскольку нарушает иммунитет от уголовной юрисдикции министра иностранных дел, предоставляемый согласно международному праву. Кроме того, десятью голосами против шести было принято решение об отмене ордера на арест и информировании об этом соответствующих властей.

Не случайно вскоре после вынесения решения по указанному делу, Бельгия внесла изменения в ряд национальных законодательных актов, во-первых, признав утратившим силу Закон о пресечении серьезных нарушений международного гуманитарного права от 1993 г., вовторых, подтвердив незыблемость иммунитетов глав государств, министров иностранных дел. В частности, согласно Закону от 5 августа 2003 г., в главу 1 вводного раздела Уголовно-процессуального кодекса Бельгии была включена ст. 1 bis, параграф 1 которой предусмотрел, что в соответствии с международным правом судебному преследованию не подвергаются:

- главы государств, главы правительств и министры иностранных дел других государств в период исполнения ими своих обязанностей, а также другие лица, пользующиеся иммунитетом на основании международного права;

- лица, обладаюшие иммунитетом (полным или частичным), предоставляемым им международным договором Бельгии.

Кроме того, согласно параграфу 2 указанной статьи было установлено, что, как того требует международное право, никакие принудительные действия, связанные с осуществлением судебного преследования, не могут предприниматься в отношении любого лица, официально приглашенного в Бельгию властями страны или международной организацией, штаб-квартира которой находится в Бельгии и с которой у Королевства имеется соглашение о статусе и деятельности этой организации. Это требование распространяется на весь период пре-

(Democratic Republic of Congo vs. Belgium), Preliminary Objections and Merits, Judgment of 14 February 2002// International and Comparative Law Quarterly. 2003. Vol. 52. № 3. P. 775-781.

${ }^{33}$ См. об изменениях бельгийского закона, в частности: Smis S., Van Der Borght. Belgian Law concerning The Punishment of Grave Breaches of International Humanitarian Law: A Contested Law with Uncontested Objectives [WWW-документ]// ASIL Insights [WWWсайт]: URL: http: // www.asil.org/insights/insigh 112.htm (2004. 6 января). 
бывания таких лиц в стране ${ }^{33}$. Необходимо также иметь ввиду, что в связи с принятием Закона от 5 августа 2003 г., Закон о пресечении серьезных нарушений международного гуманитарного права утратил силу и все вопросы, связанные с применением универсальной юрисдикции в отношении таких деяний как геноцид, военные преступления, преступления против человечности, были перенесены в сферу действия Уголовного кодекса Бельгии

Подобного рода ограничения универсальной юрисдикции представляются немаловажными и позволяют обеспечить надлежащее функционирование международного правового порядка, исключая возможные конфликты норм национального права с международными обязательствами государств.

Однако, учитывая вероятность возникновения проблем с применением абсолютной универсальной юрисдикции, в отношении деяний, совершенных за пределами Германии, стремясь, с одной стороны, не допускать перегрузки германской судебной системы, а с другой стороны, исходя из безусловного признания того обстоятельства, что такие международные преступления, как геноцид, преступления против человечности и военные преступления, должны преследоваться в соответствии с принципом территориальной уголовной юрисдикции либо компетентным международным трибуналом, немецкий законодатель предусмотрел некоторые правовые ограничения принщипа универсальности. В частности, согласно 153 (f) УПК Германии прокуратура вправе отказаться от преследования преступления, предусмотренного $\$$ 6-14 КППМП, если обвиняемый не находится на территории страны и его прибытия не ожидается. Кроме того, прокуратура вправе отказаться от преследования преступления, наказуемого в соответствии c $\$ 6$ 6-14 Кодекса, в частности в случаях, предусмотренных подпунктами 1 и 2 пункта $1 \S 153$ (c) УПК Германии, если нет оснований полагать, что: 1) преступление совершено немцем; 2) деяние не было совершено в отношении немца; 3) лицо, подозреваемое в совершении преступления, не находится на территории страны и его прибытия не ожидается; 4) преступление преследуется в международном суде или государством, на территории которого оно было совершено, либо гражданин которого обвиняется в совершении этого преступления, либо гражданину которого преступлением был причинен ущерб. Отказ от преследования может также иметь место в случаях, когда обвиняемый за преступление, предусмотренное $\$$ 6-14 и совершенное за грани- 
цей, является немцем и предполагается его передача международному суду либо выдача преследующему государству.

Среди тех вопросов, которые урегулированы в Общей части КППМП, особую важность представляют: ответственность начальников, неприменимость сроков давности, вопросы ответственности за действия по приказу или распоряжению, и именно на них необходимо остановиться подробнее.

Согласно $\S 3$ является невиновным лицо, совершающее деяние, предусмотренное $\$$ 8-14 при исполнении военного приказа или распоряжения, имеющего аналогичную обязательную силу, если оно не осознавало незаконность приказа либо распоряжения и если их незаконность не была очевидной. Указанный параграф Кодекса учитывает требования ст. 33 Римского статута, в соответствии с которой совершение лицом по приказу правительства или начальника, будь то гражданского либо военного, преступления, подпадающего под юрисдикцию Суда, не освобождает его от уголовной ответственности, за исключением случаев, когда: а) это лищо было юридически обязано исполнять приказы данного правительства либо начальника; в) это лицо не знало, что приказ был незаконным; с) приказ не был явно незаконным.

Другой важной нормой общего характера является $\S 4$ «Ответственность командиров и других начальников" ("Verantwortllichkeit militärischer Befehlshaber und anderer Vorgesetzter"). В соответствии с данным параграфом военный командир либо гражданский начальник, который, бездействуя, не препятствует совершению его подчиненными преступлений, предусмотренных Кодексом, наказывается как исполнитель преступления. Пункт $2 \S 13$ УК Германии в этом случае не применяется. Напомню, что в указанном пункте речь идет о смягчении наказания ${ }^{34}$. Кроме того, пункт $2 \S 4$ к военному командиру приравнивает лицо, которое осуществляет эффективное командование и контроль, а к гражданскому начальнику - лицо, которое осуществляет в гражданской организации либо учреждении эффективную власть либо контроль.

Рассматриваемая норма $(\S 4)$ Кодекса характеризует один из аспектов ответственности начальников за преступные деяния подчиненных, которая регламентируется такжест. 28 Статута $\mathrm{MYC}^{35}$.

${ }^{34}$ Уголовный кодекс Германии. М.: Зерцало. 2000. С. 15.

${ }^{35}$ Kittichaisaree $K$. International Criminal Court. Oxford: Oxford University Press. 2001. P. 251-257. 
Другой, не менее важной нормой является $\S 5$ «Неприменимость срока давности» ("Unverjährbarkeit"), согласно которой в отношении преследования преступлений, предусмотренных КППМП, не устанавливается никакого срока давности. Рассматриваемый параграф отражает требования ст. 29 Римского статута, которая предусматривает, что в отношении преступлений, подпадающих под юрисдикцию Суда, не устанавливается никакого срока давности.

Необходимо напомнить, что в международном праве ряд юридических инструментов регламентирует вопросы сроков давности в отношении международных преступлений. В частности, это Конвенция о неприменимости сроков давности к военным преступлениям и преступлениям против человечности, принятая резолюцией Генеральной Ассамблеи ООН от 26 ноября 1968 г. ${ }^{36}$ и Европейская конвенция о неприменимости сроков давности к военным преступлениям и преступлениям против человечности от 25 января 1974 г. ${ }^{37}$ Хотя и Германия не участвует в указанных договорах, ратификация Римского статута, ст. 29 которой закрепляет рассматриваемый принцип, обусловила введение в КППМП специальной нормы о неприменимости сроков давности. С другой стороны, неприменимость сроков давности в отношении геноцида, преступлений против человечности и военных преступлений рассматривается как норма обычного международного права, которая может быть реализована во внутригосударственном законодательстве независимо от участия в Конвенции 1968 г. либо в Европейской конвенции.

Как указывает Рене Давид, существует множество различных правовых источников, которые опираются на концегцию отсутствия сроков давности в отношении международных преступлений. В любом случае военные преступления и преступления против человечности, как и другие международные преступления, в том, что касается срока давности, должны регулироваться правопорядком, к которому принадлежат, то есть международным правом. Поскольку это право вообще отрицает срок давности, а также учитывая, что срок давности несовместим с природой признанных преступными деяний, есть все осно-

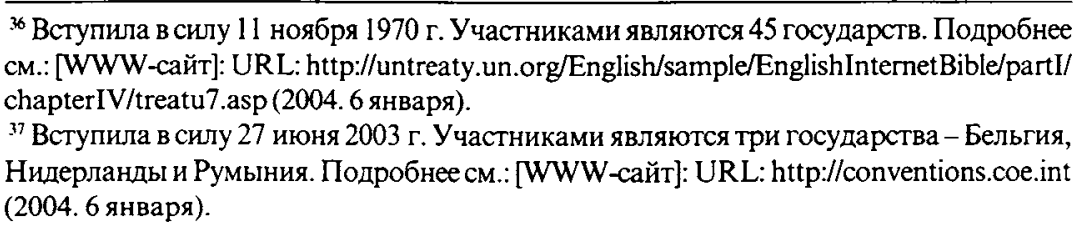


вания сделать вывод о неприменимости срока давности к этим преступлениям ${ }^{38}$.

Вместе с тем надо учесть, что неприменение сроков давности не рассматривается в качестве принципа, относящегося ко всем международным преступлениям. Это, кстати, подтверждается и многосторонней договорно-правовой практикой в сфере борьбы с международной преступностью. Однако в случае с геноцидом, преступлениями против человечности и военными преступлениями налицо прямо противоположная ситуация, которая поддерживается подходом, согласно которому запрет указанных преступлений конституирован в качестве нормы jus cogens, имеющей своим последствием неприменимость к ним сроков давности ${ }^{39}$.

Часть вторая КППМП «Уголовно-наказуемые нарушения международного права» состоит из трех разделов, охватывающих составы геноцида ("Völkermord"), преступлений против человечности ("Verbrechen gegen die Menschlichkeit") - раздел первый; военных преступлений (“Kriegsverbrechen”) - раздел второй, иных уголовнонаказуемых деяний (“Sonstige Straftaten”) - раздел третий.

Состав преступления геноцида совпадает с определением, предусмотренным в ст. 2 Конвенции о предупреждении преступления геноцида и наказании за него 1948 г. и ст. 6 Статута МУС ${ }^{40}$. Надо заметить, что Германия, после того как 24 ноября 1954 г. стала участником Конвенции $^{41}$, имплементировала свои обязательства, предусмотрев в ст. 220а Уголовного кодекса Германии ответственность за данное преступление. Небольшое отличие по сравнению с конвенционной нормой касалось понятия «этническая группа», которое в ст. 220а было сформулировано как «отличающаяся своими традициями» группа (общность). Однако в § 6 КППМП эта формулировка была заменена термином «этническая группа», что обеспечило практически полную идентичность подходов нового Кодекса со Статутом МУС.

\footnotetext{
${ }^{38}$ Давид Э. Принципы права вооруженных конфликтов. М., 2000. С. 586.

${ }^{39} \mathrm{Cм}$. об этом подробнее: Wyngaert C., Dugard J. 'Non-Applicability of Statute Limitations', in The Rome Statute of the International Criminal Court: A Commentary. 2002. Vol. I. P. 887.

${ }^{40}$ См.: Черноудова M.C. Состав преступления геноцида в международном и внутригосударственном праве (на примере законодательства и практики России и Германии) // Московский журнал международного права. 2003. № 3. С. 156.

${ }^{41}$ CM.: [WWW-caйт]: URL: http://www.unnhchr.ch/html/menu3/treatylgen.htm (2004.6 января).
} 
Согласно 6 за геноцид предусмотрено наказание в виде пожизненного либо срочного (не менее пяти лет) лишения свободы. Подобные меры наказания за преступления, подпадающие под юрисдикцию МУС, включая и геноцид, предусматривает и ст. 77 («Применимые меры наказания») Римского статута.

Новый Кодекс предусмотрел широкий перечень деяний, квалифицируемых в качестве преступлений против человечности. При этом $\S 7$ Кодекса по существу основывается на ст. 7 Статута МУС. Как известно, Римский статут Международного уголовного суда является первым международным договором универсального характера, который содержит определение преступлений против человечности ${ }^{42}$. Уже в самом начале переговоров в Подготовительном комитете было очевидно, что большинство государств не будут принимать узкую трактовку преступлений против человечности, содержащуюся в ст. 5 Устава Международного уголовного трибунала по бывшей Югославии. В результате была принята формулировка, охватывающая 11 видов действий, подпадающих под категорию преступлений против человечности, и в частности таких, как убийство, истребление, порабощение, депортация и т.д.

Новый германский Кодекс, так же как и Римский статут, давая определение преступлений против человечности, не требует увязки с каким-либо вооруженным конфликтом, хотя и оговаривает условия, при которых могут совершаться преступления против человечности: согласно $\$ 7$ «преступления против человечности» означают соответствуюшие деяния, которые совершаются в рамках широкомасштабного или систематического нападения на любое гражданское население. С другой стороны, КППМП отразил практически весь спектр деяний, которые согласно ст. 7 Римского статута квалифицируются в качестве пре-

${ }^{42}$ O преступлениях против человечности см.: Bassiouni C. Crimes Against Humanity in International Criminal Law. Sec. rev. ed. Kluwer Law International. The Hague/London/Boston. 1999; Robertson G., Roth K. Crimes Against Humanity: The Struggle for Global Justice. New Press. 2000. См. также: Robinson D. Defining "Crimes Against Humanity" at the Rome Conference // American Journal of International Law. 1999. Vol. 93. № 1. P. 237-316; Van Schaac B. The Definition of Crimes Against Humanity: Resolving the Incoherence / Columbia Joumal of Transnational Law. 1999. Vol. 37. № 3.P. 787-850; McAuliffe de Guzman M. The Road from Rome: the Developing Law of Crimes Against Humanity//Human Rights Quarterly. 2000. Vol. 22. № 2. P. 335-403; Mettraux G. Crimes Against Humanity in the Jurisprudence of the International Criminal Tribunals for the Former Yugoslavia and for Rwanda // Harvard international Law Journal. 2002. Vol. 43. № 1. P. 237-316. 
ступлений против человечности: убийство, торговля людьми, депортация либо насильственное перемещение людей в нарушение общей нормы международного права, пытки, насильственное исчезновение людей, нанесение тяжких телесных повреждений и т.д. Вместе с тем отдельные аспекты имплементации, касающиеся преступлений против человечности, в КППМП несколько отличаются от подхода ст. 7 Римского статута. В частности, это относится к последовательности изложения составов преступлений. Кроме того, формулировки некоторых составов эже по сравнению с указанной статьей Статута. К примеру, если п. “к” ст. 7 (1) Статута МУС в качестве преступления против человечности квалифицирует бесчеловечные деяния, заключающиеся в умышленном причинении сильных страданий или серьезных телесных повреждений либо серьезного ущерба психическому либо физическому здоровью, то $\$ 7$ (8) Кодекса говорит о причинении другому человеку серьезных телесных повреждений или умственного расстройства. Следует также обратить внимание на то, что, к примеру, в отличие от п. "h" ст. 7 (1) Статута применительно к такому преступлению, как преследование, $\S 7$ (10) КППМП не требует связи с другим преступлением, и в этом отношении ее формулировка шире по сравнению с соответствующей формулировкой Статута ${ }^{43}$.

Раздел второй Кодекса «Военные преступления» охватывает пять самостоятельных параграфов: $\S 8$ «Военные преступления против лищ» (“Kriegsverbrechen gegen Personen"); $\$ 9$ «Военные преступления против права собственности и иных прав» ("Kriegsverbrechen gegen Eigentum und sonstige Rechte”); $\$ 10$ «Военные преступления в отношении гуманитарных операций и эмблем» ("Kriegsverbrechen gegen humanitdre Operationen und Embleme"); 11 «Военные преступления применения запрещенных средств ведения войны» (“Kriegsverbrechen des Einsatzes verbotener Methoden der Kriegsführung"); $§ 12$ «Военные преступления применения запрешенных методов ведения войны» ("Kriegsverbrechen des Einsatzes verbotener Mittel der Kriegsführung").

Как видно из анализа статей Особенной части Кодекса, посвященных ответственности за военные преступления, их систематизация отличается от последовательности составов указанной категории преступлений, охваченных Римским статутом. В комментариях к проекту Кодекса отмечалось, что систематика военных преступлений

${ }^{43}$ См. подробнее: Wirth S. Germany's New International Crimes Code: Bringing a Case to Court. P. 157. 
в КППМП ориентируется на субстанционное развитие международного гуманитарного права, в котором за последние десятилетия сложилось разграничение между охраной (защитой) лиц и имущества, с одной стороны, (Женевское право) и ограничением применения определенных методов и средств ведения войны, с другой стороны, (Гаагское право). При этом основу систематизации составляет не характер преступления (совершение деяния в ситуации международного либо внутреннего вооруженного) конфликта, а содержание объекта посягательства ${ }^{44}$.

Другим существенным отличием КППМП от Римского статута применительно к проблеме ответственности за военные преступления явилось отсутствие порога юрисдикции (т.н. "threshold clause", “jurisdictional threshold”), как это предусматривает Статут МУС. Согласно ст. 8 (1) Римского статута предусматривается, что Суд будет обладать юрисдикцией в отношении военных преступлений, в частности когда они будут совершены в рамках плана или политики или при крупномасштабном совершении таких преступлений. Указанные критерин не являются необходимыми условиями для осушествления юрисдикции в отношении военных преступлений и не рассматриваются в качестве элементов преступлений, однако они могут быть приняты во внимание при определении того, существует ли необходимость начать расследование в отношении предполагаемого военного преступника ${ }^{45}$. Отсутствие порога юрисдикции в КППМП объясняется тем, что немецкий законодатель не посчитал указанное требование необходимым согласно обычному международному праву ${ }^{46}$. Кроме того, некоторые различия Статута МУС и нового Кодекса касаются и состава тех деяний, которые квалифицируются в качестве военных преступлений.

В целом применительно к военным преступлениям, предусмотренным КППМП, соответствующий раздел учитывает составы тех деяний, которые указаны в ст. 8 Римского статута ${ }^{47}$. Так же как и в Стату-

${ }^{4} \mathrm{C}_{\mathrm{M} .:}$ Werle G., Jessberger F. International Criminal Justice is Coming Home: The New German Code of Crimes Against International Law//Criminal Law Forum. 2002. Vol. 13. P. 207.

${ }^{45}$ Sunga $L$. The Crimes within Jurisdiction of the International Criminal Court (Part II, Articles 5-10) // European Journal of Crime, Criminal Law and Criminal Justice. 1998. Vol. 6№ 4. P. 76; Kittichaisaree K. Op. cit. P. 132.

${ }^{46}$ Wirth S. Germany's New International Crimes Code: Bringing a Case to Court. P. 157.

${ }^{47} \mathrm{CM}$.: Dormann $K$. Elements of War Crimes under the Rome Statute of the International Criminal Court. Cambridge: Cambridge University Press. 2003. 
те МУС, понятие «военное преступление» распространено на конфликты немеждународного характера. Кстати, указанное обстоятельство явилось одним из самых важных достижений Римской дипломатической конференции по учреждению МУС, хотя и надо заметить, что тенденция к одинаковому юридическому подходу в отношении конфликтов международного и немеждународного характера четко проявилась в практике Международных уголовных трибуналов $a d$ hoc ${ }^{48}$. Согласно новому Кодексу военные преступления подлежат преследованию независимо от категории вооруженного конфликта. Для этого был использован технико-юридический прием, в соответствии с которым все параграфы Кодекса, устанавливающие уголовную ответственность за военные преступления (§ 8-12), начинаются со слов «кто в связи с международным либо немеждународным вооруженным конфликтом', и далее указывается на совершение соответствующих преступлений.

Как уже отмечалось выше, в зависимости от объекта посягательства КППМП выделяет различные виды военных преступлений.

Военные преступления против лиц предусматривают составы таких деяний в отношении зашишаемых согласно международному гуманитарному праву лиц, как:

умышленное убийство $(\S 8(1,1))$;

взятие в заложники $(\S 8(1,2))$;

жестокое или бесчеловечное обращение, сопряженное с причинением серьезных телесных повреждений либо умственного расстройства, включая пытки $(\S 8(1,3))$;

${ }^{48} \mathrm{Cм.} \mathrm{в} \mathrm{частности,} \mathrm{решение} \mathrm{Международного} \mathrm{уголовного} \mathrm{трибунала} \mathrm{по} \mathrm{бывшей} \mathrm{Юго-}$ славии по делу Prosecutor vs. Tadic. В частности, Трибуналом было отмечено, что начиная с тридцатых годов происходило постепенноестирание различий между нормами обычного международного права, которые регламентируют международные вооруженные конфликты, и обычными нормами, регулирующими внутренние вооруженные конфликты. В результате сближения этих норм в настоящее время внутренние вооруженные конфликты в значительной степени регулируются нормами, которые ранее применялись лишь в период международных вооруженных конфликтов. При этом Апелляционной камерой в постановлении от 2 октября 1995 г. по данному делу было указано, что нарушения законов и обычаев войны, допущенные в ходе немеждународного вооруженного конфликта, являются военными престуллениями. См. об этом подробнее: Prosecutor vs. Dusko Tadic, Decision of the Defence Motion for Interlocutory Appeal on Jurisdiction. Case No. IT-94-1-AR72. Oct. 2. 1995. См. также: Alvarez J. Nuremberg Revisted: The Tadic Case // European Journal of International Law. 1996. Vol. 7. № 2. P. 245-265; International Criminal Law. Cases and Materials. Carolina Academic Press, 2000. P. 561-564; Bohlander $M$. Prosecutor vs. Dusko Tadic: Waiting to Exale // Criminal Law Forum. 2000. Vol. 11. № 2. P. 217-248. 
принуждение лица к сексуальным действиям либо сексуальное насилие, принуждение к проституции, принудительная беременность $(\S 8(1,4))$;

набор либо вербовка детей в возрасте до пятнадцати лет в состав вооруженных сил или групп либо их использование для активного участия в боевых действиях $(\S 8(1,5))$;

депортация либо насильственное перемещение лица из района законного пребывания, насильственное перемещение его в нарушение общей нормы международного права путем выселения либо с помощью иных принудительных действий в другое государство либо в другой район $(\S 8(1,6))$;

серьезное наказание по приговору, в частности смертная казнь либо лишение свободы, либо приведение подобных приговоров в исполнение без соблюдения процессуальньх гарантий, являющихся обязательными согласно международному праву $(\S 8(1,7))$;

создание опасности причинения смерти либо тяжкого вреда здоровью (медицинские либо иные эксперименты, взятие тканей либо органов, применение методов лечения, не признаваемых медициной, без медицинской необходимости и без предварительного добровольного и прямого согласия) $(\$ 8(1,8))$;

оскорбительное либо унижающее обращение с лицом $(\S 8(1,9))$;

ранение лиц, выведенных из строя $(\S 8(2))$.

Согласно 8 (3) предусмотрена ответственность за незаконное лишение свободы лица либо неоправданную задержку его репатриации $(\S 8(3,1))$, перемещение части собственного гражданского населения на оккупируемую территорию $(\S 8(3,2))$; принуждение лица к службе в вооруженных силах неприятельской державы с применением насилия либо угрозой причинения значительного вреда $\S 8(3,3)$; принуждение гражданина противостоящей стороны к участию в военных действиях против его собственной страны с применением насилия либо угрозой причинения значительного вреда $(\S 8(3,3))$. Указанные в $\S 8(3)$ деяния могут совершаться только в ситуации международного вооруженного конфликта, в связи с чем в данном параграфе предусмотрена соответствующая ссылка.

Поскольку $\S 8$ использует термин «пицо, защищаемое согласно международному гуманитарному праву», для целей применения данного параграфа согласно части 6 в качестве таковых рассматриваются: 1) в международном вооруженном конфликте: защищаемые лица 
в смысле Женевских конвенций и Дополнительного протокола I, а именно раненые, больные, лица, потерпевшие кораблекрушение, военные и гражданское население; 2) в немеждународном вооруженном конфликте: раненые, больные, лица, потерпевшие кораблекрушение, а также лица, не принимающие активного участия в военных действиях и находящиеся под властью неприятельской стороны; 3) в международном в немеждународном вооруженном конфликте: военнослужащие и комбатанты неприятельской стороны, сложившие оружие либо в иной форме не располагающие средствами защиты.

Военные преступления против собственности и иных прав (§9) включают такие деяния, как:

разграбление или без необходимости, вызванной вооруженным конфликтом, иным образом в существенном объеме вопреки международному праву уничтожение, присвоение или захват имущества противника, находящегося под собственной властью $(\S 9(1))$. В отличие от Римского статута состав преступления, предусмотренного 99 (1), ограничивается условием «существенного объема». Подобного рода ограничение представляется целесообразным, т.к. позволяет исключить в качестве преступления случаи совершения действий, связанных с незначительным по своему объему причинением ущерба. Кроме того, надо иметь в виду, что отмеченная норма может применяться только в ситуации международного вооруженного конфликта;

отмена или приостановление либо воспрепятствование осуществлению в суде прав либо подаче исков всех либо существенной части граждан противника $(\S 9(2))$.

Военные преступления в отношении гуманитарных операций и эмблем (\$10) охватывают:

нанесение ударов по миссиям гуманитарной помощи или миссиям по поддержанию мира $(\S 10(1), 1)$;

нанесение ударов по персоналу, объектам, медицинским учреждениям либо медицинским транспортным средствам, использующим отличительные эмблемы, предусмотренные Женевскими конвенциями $(\$ 10(1), 2)$;

ненадлежащее использование отличительных эмблем, флага парламентера либо флага, военных знаков различия неприятеля или $\mathrm{OOH}$, имеющих следствием смерть либо причинение тяжкого телесного повреждения (§ 10 (2)). Если Статут МУС применяет данную норму лишь к международному вооруженному конфликту, то 
КППМП распространяет ее действие также на немеждународный вооруженный конфликт.

Военные преступления применения запрещенныхметодов ведения войны предусматривают:

нападение на гражданское население либо на отдельных гражданских лиц, не принимающих непосредственного участия в военных действиях (§ $11(1), 1)$;

нападение на гражданские объекты $(\S 11(1), 2)$;

нападение, связанное с причинением несоизмеримого вреда гражданским лицам либо ущерба гражданским объектам $(\$ 11(1), 3)$. Сфера использования данной нормы расширена по сравнению со ст. 8 Статута МУС, поскольку она применятся также к вооруженному конфликту немеждународного характера;

использование лиц, защищаемых международным гуманитарным правом в качестве «живого щита» $(\$ 11(1), 4)$;

совершение в качестве способа ведения войны действий, подвергающих гражданское население голоду путем лишения его необходимых предметов либо созданием препятствий для предоставления помощи (§ 11 (1), 5). В отличие от Римского статута, данная норма охватывает оба вида вооруженных конфликтов;

осуществление военных действия без пощады $(\S 11(1), 6)$. Согласно данной норме предусматривается ответственность командира, который отдает соответствующий приказ либо угрожает, что пощады не будет;

вероломное убийство либо ранение военнослужащего вооруженных сил противника либо комбатанта противника (§ 11 (1), 7);

причинение обширного, долгосрочного и сушественного ущерба окружающей среде $(\S 11$ (3)).

Военные преступления применения запрещенных средств ведения войны (\$ 12) включают:

применение яда либо отравленного оружия $(\S 12(1,1))$;

применение биологического либо химического оружия $(12(1,2))$. Хотя данный состав и предусмотрен ст. 8 (2, "b" (xvii)) Римского статута, сфера его применения в КППМП шире, поскольку она охватывает ситуацию как международного, так и внутреннего вооруженного конфликта;

применение легко разрывающихся либо сплющивающихся пуль $(\S 12(1,3))$. В отличие от соответствующего регулирования, предус- 
мотренного Статутом МУС (ст. 8 (2, “b” (хіх)), данная норма применяется в отношении обоих видов вооруженных конфликтов;

причинение смерти либо тяжких телесных повреждений гражданскому лицу в результате совершения действий, предусмотренных $\S 12(1)$.

Отдельный раздел Кодекса (третий) посвящен иным преступлениям и предусматривает ответственность за такие уголовно-наказуемые деяния, как нарушение обязанности осуществлять надзор (§ 13); недонесение о преступлении (\$14).

Согласно 13 , военный командир либо гражданский начальник, не осуществляющие должным образом надзора за лицом, находящимся под их командованием либо подчинением либо эффективным контролем, подлежат уголовной ответственности и наказанию в том случае, если подчиненный совершает предусмотренное настоящим Кодексом деяние, о котором командир (начальник) был осведомлен и которое он мог предотвратить. Тем самым $\S 13$ КППМП учел требования ст. 28 Римского статута, предусматривающей в дополнение к другим основаниям уголовной ответственности за преступления, подпадающие под юрисдикцию МУС, ответственность командиров и других начальников за ненадлежащее осушествление контроля за своими подчиненными, совершившими преступления против человечности, военные преступления и т.д. ${ }^{49}$ Что же касается $\S 14$, он устанавливает ответственность военного командира либо гражданского начальника, который не сообщает компетентному органу о совершении деяния, предусмотренного Кодексом.

Таким образом, общая оценка нового Кодекса, с одной стороны, свидетельствует о стремлении к созданию юридического режима, препятствующего безнаказанности лиц, виновных в совершении геноцида, военных преступлений и преступлений против человечности, с другой стороны, позволяет говорить о достаточно объемной и полной имплементации норм Римского статута МУС, позволяющей Германия самостоятельно преследовать обвиняемых, исключая возможную передачу производства по делу Международному уголовному суду.

${ }^{49} \mathrm{C}$ м. об зтом подробнее: Fenrick $W$. 'Article 28 - Responsibility of commanders and other superiors', in Commentary on the Rome Statute of the International Criminal Court: Observers' Notes, Article by Article. P. 515-522. 